\title{
Contracture of the Quadriceps Muscle in Adult
}

\author{
By \\ Toshio Amano, Hideo Watanabe, Katsumi Ogata and Toshiko Okabe \\ Department of Orthopedic Surgery, Kumamoto University \\ Medical School, Kumamoto \\ (Director : Prof. Toshio Kitagawa)
}

There have been lots of reports concerning the quadriceps muscle contractures in children. The reports of adult cases, however, are very rare until now. This report is of the quadriceps muscle contractures in healthy adults.

1. Materials and methods

445 healthy adults from 18 to 82 years old were examined. And 30 male persons who were the members of the rugby team in our medical school were also examined. The age distribution of the team were from 18 to 26 years of age. All these persons have no present problem which need medical treatment. So as to detect the quadriceps muscle contracture, all of the above mentioned adults were examined the angle of knee flexion with the extended hip joint under prone position; so called buttock elevation phenomen (Shiri-agarigensyo).

And every person with the positive phenomen above mentioned received following checks, namely (1) angle of knee flexion with hip maximally flexed position, (2) hindrance of activities of daily living (ADL) in such movements as sitting, walking, running, (3) the skin change at thigh region such as scar, depression, induration, (4) the history of receiving local intra-muscular injection at the thigh, (5) awareness of abnormality conrerning the muscle contracture, and (6) anamnesis of the disease with spine or lower extremity involvements.

2. Results
The rectus femoris mucsle contractures were detected in 92 persons (20.7\%) out of 445 examined healthy adults (Table 1). Frequency of positive buttock elevation phenomen was higher in male $(65 / 173$ persons; $37.6 \%)$ than female $(27 / 272$ persons; $9.9 \%)$. As far as concerning the age and frequency of the positive phenomen, a female from 18 to 29 yearold group showed lowest occurrence (7.1\%) and the male group over 50 years old showed the highest occurrence (42.9\%). The frequency of the positive phenomen was very high in the rugby team members, which was 23 out of 30 persons (76.7\%).

The average angle of knee flexion with extended hip of 92 positive phenomen persons or 164 suffered extremities was $111.9^{\circ} \pm 3.2^{\circ}(\mathrm{p}<$ 0.05) (Table 2). There was no meaningful difference of the average angle concerning the sexes or the side of suffered extremities. The average angle of knee flexion with extended hip of 23 positive phenomen persons from rugby team, however, was worse such as $105.1^{\circ} \pm 6.0^{\circ} \quad(\mathrm{p}<0.05)$.

Concerning the ADL, sitting trouble in Japanese way was found in 33 cases ( $35.9 \%$ ), and walking disturbance was detected only in 3 cases ( $3.3 \%$ ) (Table 3 ). As far as anterior thigh skin is concerned, only one case (1.1\%) had a depression of the skin, and the others were perfectly normal. 6 persons $(6.5 \%)$ reported the history of local injections on the anterior thigh region. None was aware of 
Table 1 Frequency of positive buttock elevation phenomen in healthy adults

\begin{tabular}{|c|ccc|cc|cc|cc|c|c|}
\hline Sex & Age & $18-29$ & Yrs. & $30-49$ & Yrs. & $50-82$ 'Yrs. & All cases & $\begin{array}{l}\text { Unilateral } \\
\text { involvement }\end{array}$ & $\begin{array}{c}\text { Bilateral } \\
\text { involvement }\end{array}$ \\
\hline Male & cases & $54 / 144$ & 38.8 & $8 / 22$ & 36.4 & $3 / 7$ & 42.9 & $65 / 173$ & 37.6 & $15 / 65$ & $50 / 65$ \\
Female & $17 / 239$ & 7.1 & $7 / 21$ & 33.3 & $3 / 12$ & 25.0 & $27 / 272$ & 9.9 & $5 / 27$ & $22 / 27$ \\
\hline Total & $71 / 383$ & 18.5 & $15 / 43$ & 34.9 & $6 / 19$ & 31.6 & $92 / 445$ & 20.7 & $20 / 92$ & $72 / 92$ \\
\hline
\end{tabular}

Rugby team : $23 / 30$ cases $76.7 \%$ (All males: age 18-26 yrs.)

Table 2 Average angle of knee flexion with extended hip (92 cases : 164 extremities)

\begin{tabular}{|c|c|c|c|c|c|c|}
\hline Sex Age & $18-29$ Yrs. & $30-49$ Yrs. & $50-82$ Yrs. & All cases & Right $\mathbf{n}: 79$ & Left $\mathrm{n}: 87$ \\
\hline Male & $\begin{array}{r}109.9^{\circ} \pm 4.5^{\circ} \\
\left(45^{\circ}-135^{\circ}\right)\end{array}$ & $\begin{array}{r}120.7^{\circ} \pm 8.4^{\circ} \\
\left(90^{\circ}-135^{\circ}\right)\end{array}$ & $\begin{array}{r}106.0^{\circ} \pm 26.8^{\circ} \\
\left(80^{\circ}-130^{\circ}\right)\end{array}$ & $111.0^{\circ} \pm 3.9^{\circ}$ & $110.3^{\circ} \pm 6.3^{\circ}$ & $111.6^{\circ} \pm 5.4^{\circ}$ \\
\hline Female & $\begin{array}{r}116.3^{\circ} \pm 7.3^{\circ} \\
\left(55^{\circ}-135^{\circ}\right)\end{array}$ & $\begin{array}{l}121.1^{\circ} \pm 5.3^{\circ} \\
\left(110^{\circ}-130^{\circ}\right)\end{array}$ & $\begin{array}{r}86.7^{\circ} \pm 23.6^{\circ} \\
\left(60^{\circ}=110^{\circ}\right)\end{array}$ & $114.0^{\circ} \pm 5.8^{\circ}$ & $116.8^{\circ} \pm 7.4^{\circ}$ & $111.2^{\circ} \pm 9.5^{\circ}$ \\
\hline Total & $111.8^{\circ} \pm 3.5^{\circ}$ & $120.9^{\circ} \pm 4.7^{\circ}$ & $95.5^{\circ} \pm 15.6^{\circ}$ & $111.9^{\circ} \pm 3.2^{\circ}$ & $112.3^{\circ} \pm 5.0^{\circ}$ & $111.5^{\circ} \pm 4.7^{\circ}$ \\
\hline
\end{tabular}

Rugby team: $105.1^{\circ} \pm 6.0^{\circ}$ (Right $108.2^{\circ} \pm 10.1^{\circ}$, Left $\left.102.2^{\circ} \pm 7.5^{\circ}\right) \quad(\mathrm{p}<0.05)$

Table 3 Hindrance of ADL and other findings

\begin{tabular}{|l|cc|}
\hline ADL Abnormal of sitting & $33 / 92$ persons & $35.9 \%$ \\
Abnormal of walking & $3 / 92$ & 3.3 \\
Abnormal of running & $2 / 92$ & 2.2 \\
Skin change at thigh & $1 / 92$ & 1.1 \\
History of local injections & $6 / 92$ & 6.5 \\
Awarness of anbormality & $1 / 92$ & 1.1 \\
Anamnesis of spine and lower extremities involvements & $12 / 92$ & 13.0 \\
\hline
\end{tabular}

suffering from the quadriceps muscle contracture except one (1.1\%).

3. Discussion and summary

Case reports of quadriceps muscle contracture in children are not $f\left(w^{1)^{25}}\right)^{7}$, and mass examination survey ${ }^{6)}$ has been done as well.

We detected fairly numerous adults with the muscle contracture, and the part of it was reported lately ${ }^{8)}$. The majority of the cases had rectus femoris muscle contractures, but 5 cases $(5.4 \%)$ were suffered from the contracture of vastus intermedius muscle, too. Degrees of severity of the rectus femoris muscle contractures, however, were mild in majority, and there were moderate numbers of disturbance in ADL when sitting and running.

Though the cause of the contracture in adult has not been determined yet, this study pointed out the necessity of further investigations to adult people concerning the disease.

\section{References}

1) Hagen, R.: Acta Orthop. Scand., 39:565, 1968.

2) Kasai, Z. et al.: Seikei Geka (Orthopedic Surgery), 15: 631, 1964 (Japanese).

3) Lénárt, G. et al.: Clin. Orthop., 99: 125, 1974.

4) Negishi, A. et al.: Seikei Geka (Orthopedic Surgery), 21 : 349, 1970 (Japanese).

5) Sato, K. et al.: Shyoni Igaku (Pediatric Review), 9: 699, 1976 (Japanese).

6) Wakamatsu, E. et al.: Nihon Ishikai Zashi (J. Japan Med. Assoc), 75: 505, 1976 (Japanese).

7) Watanabe, H. et al.: Seikeigeka to Saigaigeka (Orthopedics and Traumatology), 
25: 363, 1976.

8) Watanabe, H. et al.: Igaku no Ayumi, 102: 33, 1977 (Japanese).

抄 録

大腿四頭筋拘縮症の成人例

$$
\text { について }
$$

熊本大学医学部整形外科

$$
\begin{array}{lll}
\text { 天 } & \text { 野 } & \text { 敏 } \\
\text { 渡 } & \text { 辺 } \\
\text { 英 } \\
\text { 尾方 } \\
\text { 克 } \\
\text { 岡 } \\
\text { 部 とし子 }
\end{array}
$$

大腿四頭筋拘樎症（以下拘縮症）は今までに多数の 症例報告がある. しかしその大半は小児例であり，成 人についての報告は少ない，成人についての拘縮症の 有無, 頻度, 程度, 日常生活動作などに 対する 影響 を，今回健康成人 445 人について調査した．その他に ラグビー部員 30 人についても運動と拘縮症との 関連 を調べるため同様の調査を行なった.

その結果 445 人中 92 人に拘縮症が 発見された. ま
たラグビー部員では 30 人中 23 人に発見された．その 程度は軽いものが大半であったが日常生活動作では正 坐の異常を訴えたあのが全体の約 $1 / 3$ にあった.

また若い男性特に運動を常時行なっているものに拘 縮症の発生が多い傾向にあった.

若い女性では比較的少なかった。

原因として注射によると考えられる例は少なかっ た. 成人拘縮症は小児例に比へ，その原因や症状にか なりの違いがあると思われた.

罂 問 北里大学整形 山本 真 (座長) 厚生省研究班の報告では注射だけの原因以外に小児 例の要素ああるとなっているとのことですが，演者の 御意見をおききしてみたい.

回答熊本大学整形 天野 敏夫 大腿四頭筋拘縮症の原因として，注射以外の，例え ば筇の再生能力の低下や，体質，生活習慣などの影響 あ考えられる. 特に成人では注射によると思われる例 は，極く少なかった. 